\title{
Kurdish EFL Students Teachers' Practicum Experience: Some Basic Challenges
}

\author{
Barham Sattar Abdulrahman \\ Department of English, College of Basic Education, University of Sulaimani, \\ Sulaymaniyah, Kurdistan Region - F.R. Iraq \\ Department of English Language, University College of Goizha, \\ Sulaymaniyah, Kurdistan Region - F.R. Iraq
}

\begin{abstract}
The present study highlights the main challenges faced by EFL student teachers (STs) of the Department of English - College of Basic Education - University of Sulaimani during their teaching practice. To investigate the challenges, a closed-ended questionnaire is designed which consists of 20 items focusing on a variety of relevant issues of practicum experience. The questionnaire is given to $50 \mathrm{EFL}$ STs and the collected data is statistically analyzed. The study hypothesizes that EFL STs might have serious challenges in their teaching at basic schools, which could be related to the lack of motivation of basic school students, shortage of practicum period, supervisors' evaluation, and lack of teaching technology. These challenges are proved true after the analysis of the data. Based on the conclusions of this current study, it is recommended that Kurdish EFL STs should be familiarized with different aspects of teaching profession. To this end, the university stakeholders should design a specialized program for ST practicum and create a strong link with basic school programs. The conclusions and recommendations could be taken into consideration by the STs, university teaching staff, and basic school principals to overcome the challenges and improve the practicum process. Thus, the study could have potentially significant implications for the senior administrators of the Department of English, College of Basic Education deanery, and the University of Sulaimani presidency for addressing the main challenges of practicum faced by EFL STs.
\end{abstract}

Index Terms-Teaching Challenges, Practicum, EFL, Supervision, Teaching, Learning, Evaluation.

\section{INTRODUCTION}

It is undeniable that teaching, especially teaching a foreign language, is not an easy task since it "involves a complex cycle of planning, acting, observing, and reflecting" (Loucks-Horsley et al., 2010, p. 64). So, it is a prerequisite for someone who intends to be a language teacher to have practicum. The reason behind this could be attributed to the fact that practicum can be considered as basic requirements of being a teacher since a student teacher learns more about his/her future career (Marais \& Meier 2004; Ogonor \& Badmus, 2006; Farrell 2007). This may lead someone to claim that in order to focus on preparing well-qualified teacher, there should be practicum in the field of teaching because the process of teaching practice makes STs ready for teaching scientifically and professionally. This journey of transformation from being a student to be a teacher, as Hoben and Brickell (2006) claims, is very complex and challenging. In brief, as Gebhard (2006) believes, teaching is a multi-dimension and complex process since learning to assume roles in English could be problematic for learners/teachers.

Teachers can be regarded as one of the important components of the teaching/learning process since they work on accomplishing the main aims of education, e.g., positively changing the students behaviour, working on the students' cognitive, emotion, social and physical aspects, etc. To achieve all of these, universities especially colleges of education, basic education, teachers, etc. should pay more attention to teach practicum at the last academic year of the college study. The colleges should design a well-structured curriculum for this purpose. The reason behind this might be related to what has been mentioned by Tarone and Allwright (2005, p. 12) that "the discontinuity between these academic content courses and the language classroom appears to set up a gap that cannot be bridged by beginning teacher learners".

In EFL contexts, most universities offer numerous English programs. Almost all programs include different courses on related subjects to English such as grammar, vocabulary, literature, listening and speaking, reading and writing, etc. (Gebhard, 2006). In order to prepare language teachers, English programs should be more practical-oriented, i.e., the programs should offer different subjects related to teaching methodology, assessment, educational psychology, class management, etc. Richards (2012, p. 49) state that language teachers need to

Journal of University of Human Development

Volume 5 No. 2(2019); DOI: 10.21928/juhd.v5n2y2019.pp13-19

Regular research paper: Received 12 February 2019; Accepted 09 March 2019; Published 10 April 2019

Corresponding author's e-mail: barham.abdulrahman@univsul.edu.iq

Copyright (C) 2019 Barham Sattar Abdulrahman. This is an open access article distributed under the Creative Commons Attribution License

(CC BY-NC-ND 4.0) 
learn/acquire contextual knowledge that appropriately works and enables teachers to function more practical. In other words, language teachers are in need of having a better understanding about learning to teach; this creates a clear image of "the dynamics and relationships within the classroom and the rules and behaviours specific to a particular setting".

In fact, a well-structured practicum assists STs to gain more knowledge about the teaching/learning process. It decreases the amount of challenges which may face STs during their practicum experience and their career in the future. To achieve this, colleges that prepare language teachers should design their curricula in accordance with Johnson's (2009) claim that in second (or foreign) language teacher preparation program, three fundamental aspects should be taken into account: the program content (what teachers need), pedagogy and teaching methodology (how teachers teach), and forms and ways of learning second/foreign language teaching content and pedagogy (how teacher learn to be teachers).

Finally, Darling-Hammond and Chung (2002) believe that the practicum program should be highly systematic since it results in having better teaching performance. Besides, there should be a good connection between the theoretical knowledge the STs take and practicum.

\section{The Concept of Teaching Practicum And Its Purpose}

According to Atiya and Alhashmi (2008 cited in Abu Omar et al. 2018, p. 49), the concept of teaching practicum refers to "the practical side of the student teachers preparation and qualification programs that provide student teachers with needed knowledge and skills to perform teacher's roles and responsibilities, where the student teachers practice these roles and responsibilities in the classroom or outside the classroom under the supervision of the university practicum supervisor in collaboration with the school administrations and teachers". In general terms, there is a sort of agreement among many scholars that practicum of teaching can be considered as a key aspect in any related programs to teacher education (Glickman \& Bey, 1990; Mclntyre, Byrd, \& Fox, 1996, cited in Beck \& Kosnik, 2002). The reason is attributed to the fact that practicum gives new experience to learners especially when they take part in the process of teaching. In addition, it makes STs understand their own role in the process and change their perspective about education in general (Handal \& Lauvas, 1987).

According to Price (1987 cited in Ryan et al. 1996, p. 356), the main purpose behind practicum is linking theory to practice. This could be achieved through supervising STs in applying and assessing the knowledge and skill they acquired/learned at university in the real world of education, teaching and school environment. So, practicum translates theory into practice. In other words, the STs apply different knowledge they gain and skills they acquire from their academic courses to the context where they teach and work (cf. Collinson et al. 2009; LoucksHorsley et al. 2010). Moreover, Ogonor and Badmus (2006) state that practicum provides a sort of training that expose STs to classroom realities. The STs also test the theories they have taken during their academic study and use different methods of teaching in real classroom atmosphere under the supervision of university-based and school-based supervisors (cf. Zeichner, 2006). In brief, the STs are going to be responsible in teaching and managing their classes. This, of course, is challengeable on one hand. One the other hand, practicum experience increases the STs' self-confidence and develops their teaching performance. Furthermore, Britzman (1991, p. 46) states that besides putting the university obtained knowledge into practice, STs "are expected to transform this received classroom knowledge, shifting from a student's perspective to that of a teacher" and in fact this can be considered as the most challengeable work in this regard. Finally, one may state that the main aim of practicum experience is to make and prepare good teachers in the future. In fact, good teachers are fair, reasonable, enthusiastic, efficient, well organized, available, well prepared, impartial, helping and motivating students, accessible, interested in their subjects, and using good verbal/nonverbal skills to teach and guide students, etc. (cf. Prebble et al., 2004).

\section{Teaching Practice at College of Basic Education, UNIVERSITY OF SULAIMANI}

\section{A. Observation and Practicing}

As a separate subject in the English Department curriculum, "Observation and Practicing" takes place in the first semester of the last academic year. This course is designed to make the fourth year students familiar with the school atmosphere. As part of this course, the students are expected to be ready to visit basic schools and observe teachers in the first semester, whereas in the second semester they do teaching practice. This means in the final stage of their academic study, Kurdish EFL undergraduates visit basic schools to observe and apply knowledge they acquire during their study. As it is expected, STs learn more about teaching process through pedagogical practicum. Kumaravadivelu (2006) believes that the majority of teacher education programs are intended to transmit a welldesigned knowledge from university lecturers to STs. This, in fact, can be accomplished via practicum which refers to an approach in which STs teach their classes and university-based supervisors observe them in order to make the STs' teaching style better. Furthermore, the supervisors provide STs with necessary feedback, recommendations, and suggestions.

\section{B. Teaching Practice}

As one of the requirements of fulfilling Bachelor of Basic Education, all undergraduates must practice teaching at basic schools for a number of weeks. So, teaching practice can be regarded as a mandatory subject within the English Department, College of Basic Education curriculum. After studying different subjects related to English language, syntax, vocabulary, literature, teaching methodology, educational psychology, etc., the fourth year students visit basic schools to practice their teaching skills. The students teach English as a foreign language for (45) days at basic schools; they do behave as school teachers having responsibility, designing questions, managing examinations, etc. So, in Kurdish EFL context, the concept of practicum refers to experiences that STs have inside 
a basic school before their graduation. This means the STs are assigned to teach (1-9) grades and supervised by universitybased supervisors, cooperating teachers, and the school principal. Furthermore, this procedure gives the STs an opportunity to experience real classroom teaching and improves the skills they need for their future career. In brief, the practicum may goes in accordance with what has been mentioned by Mills (1980, p. 5) that in spite of the fact that ST regularly observe classes in earlier stages, "they typically observe as they grade papers, help pupils with seatwork, and perform other clerical tasks for supervising teachers, or, they sit quietly and 'look' without training in the skills of observation".

Richards (2012) claims that teaching English can be considered as a profession since it requires appropriate knowledge received from the academic study and practicing. The following diagram explains the practicum process at the College of Basic Education, University of Sulaimani.

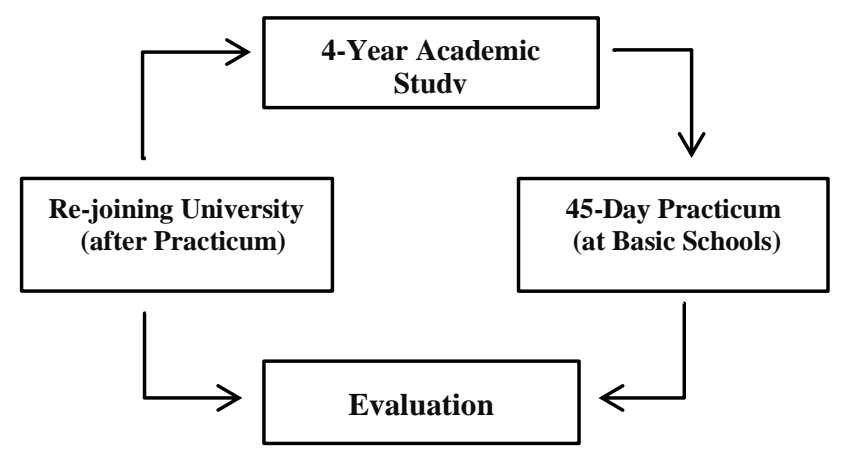

Fig. 1. Practicum Cycle at College of Basic Education, University of Sulaimani

Stodolsky (1984 cited in Bailey, 2009, 708) claims that "evaluation of teachers rests on the assumption that the characteristics of good or effective teachers are known and recognizable". Concerning the evaluation process, it is worth mentioning that there are four evaluators who evaluate the STs' performance: scientific supervisor, educational supervisor, lecturers of Observation and Practicing, and basic school principal. Consider the following figure:

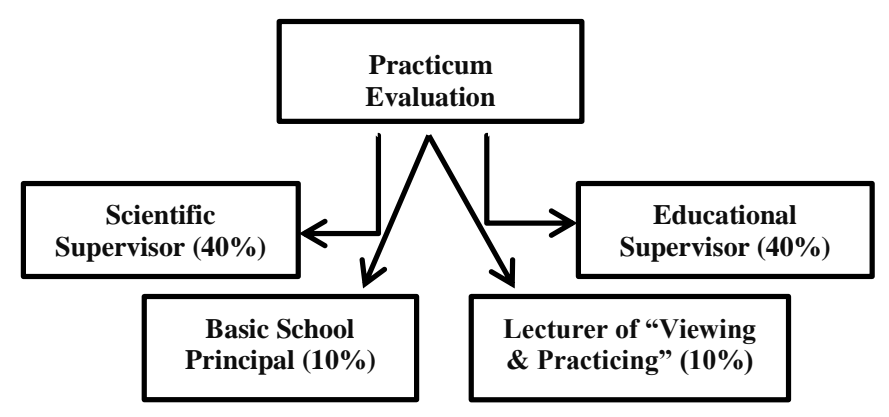

Fig. 2. ST Evaluation Process

\section{Methodology}

\section{A. The Research Instrument}

A questionnaire is used which consists of 30 Likert-scale items in three different categories (agree, neutral, and disagree). After consulting a number of experts, the instrument is modified by the researcher and only 20 items remained. In order to estimate the reliability of the study instrument, the test-retest method is applied. The questionnaire reliability is 0.69 which seems that it has high coefficient reliability.

\section{B. The Procedure}

In order to collect the relevant data, the study tool was administered to a group of 50 EFL 4th year undergraduates at the Department of English- College of Basic EducationUniversity of Sulaimani during the academic year 2017-2018. The student teachers have no pervious teaching experience and they are expected to be well-prepared to the purpose of teaching. The data obtained from the questionnaire is statistically analyzed in order to find out the challenges facing EFL student teachers while practicing their teaching knowledge, skills, ability, etc.

\section{DATA ANALYSiS AND RESUlts}

The collected data has been analyzed according to some certain statistical procedures. The researcher has found coefficient midst (CM) and percentage weight (PW) of each single item. The results reveal that 7 items of the study questionnaire are not accomplished, i.e., their coefficient midst do not reach 2 and this extends from 1.6 to 1.98 and the percentage weight from 53.3 to 66 . According to the analyzed data, it is revealed that the percentage of item achievement is $65 \%$. Building on this, 13 items are achieved since their coefficient midst is above 2. These items are considered as strength ones. The coefficient midst of the accomplished items rages between 2.12 and 2.74 , and their percentage weight starts from 70.0 to 91.3 . Among all the items, 1.7 and 2.38 are the most frequent coefficient weights. Furthermore, item no.3 comes in the first rank with CM 2.74 and PW 91.3, whereas item no. 18 comes in the last rank with the value of $\mathrm{CW} 1.6$ which equals to 53.3 .

\section{A. Challenges of Teaching Basic School Students}

The first and second items of the questionnaire are designed to show the possibility of using English in teaching and the preferred teaching methodology by basic school students. As the analyzed data shows, item no.1 Basic school teachers have used L1 and I cannot use L2 most of the time ranks seventh with the CM 2.46. This confirms that the majority of EFL basic school teachers use Kurdish language rather than English while teaching and this creates a serious problem for STs. Moreover, the basic school teachers' teaching methodology may negatively affect the STs' teaching style during practicum period. According to the result of the second item, Basic school students prefer traditional methods of learning/teaching, a great number of STs face challenges while applying a new 
approach, technique, or method in teaching English. In addition, lack of motivation by basic school students can be measured as one of the serious challenges of practicum. Item no.5, Basic school students are motivated to learn English, reveals the fact that STs believe that students of basic schools are not motivated and this creates problems for teachers. The $\mathrm{CM}$ of this item is 1.98 and its PW is 66; it is a challengeable issue.

TABLE 1

Coefficient Midst (CM) And Percentage Weight (PW) of Teaching CHALLENGES ITEMS

\begin{tabular}{clrrrc}
\hline \hline No & \multicolumn{1}{c}{ Item } & CM & PW & Challenge? \\
\hline 2 & $\begin{array}{l}\text { Basic school } \\
\text { traditional } \\
\text { learning/teaching }\end{array}$ methods & $\begin{array}{r}\text { prefer } \\
\text { of }\end{array}$ & 2.56 & 85.3 & Yes \\
$1 \quad \begin{array}{l}\text { Basic school teachers have used L1 } \\
\text { and I cannot use L2 most of the time }\end{array}$ & 2.46 & 82 & Yes \\
5 & $\begin{array}{l}\text { Basic school students are motivated } \\
\text { to learn English }\end{array}$ & 1.98 & 66 & Yes \\
\hline \hline
\end{tabular}

There is no doubt when STs first enter a class and touch reality, they face many problems. Thankfully, as the data shows, the STs are successful in applying the theoretical knowledge they have studied during their academic study. Item no. 20 which is I am able to use English while teaching is achieved, because its value is 2.64. This indicates that the majority of STs are able to use English while teaching basic school students. Moreover, because of having necessary information about the textbook, the STs are able to teach and explain the topics. Regarding the challenging of writing lesson plans and designing question for the course exam, the results show that STs can overcome these problems. The following table shows CM and PW of different items $20,6,7$, and 8 .

TABLE 2

COEFFiCient Midst (CM) And PeRCEnTAge Weight (PW) OF Items NO. $(20,6,7,8)$

\begin{tabular}{ccccc}
\hline \hline No & Item & CM & PW & Challenge? \\
\hline 20 & $\begin{array}{c}\text { I am able to use English while } \\
\text { teaching. }\end{array}$ & 2.64 & 88 & No \\
6 & I am able to write a lesson plan. & 2.66 & 88.6 & No \\
7 & $\begin{array}{c}\text { I am able to explain all topics since } \\
\text { I have an idea about the textbook. }\end{array}$ & 2.48 & 82.6 & No \\
& I am able to design questions for \\
course exam. & 2.38 & 79.3 & No \\
\hline \hline
\end{tabular}

\section{B. Challenges of Supervisors' Evaluation}

Bailey (2006) claims that university-based supervisors do not have enough time to devote to each ST. This creates a sort of problem that supervisors may not visit STs regularly. Regarding EFL practicum at the University of Sulaimani, one should refer to the fact that supervisors may work with at least 10 STs and this is not helpful to visit each ST more than once during the practicum period. This negatively affects the evaluation process since supervision can be regarded as one of the most important elements of teaching practice. He (2009, p. 264) claims that "without adequate communication between mentors and pre-service teachers regarding teaching expectations and beliefs, pre-service teachers leave the teacher education programs ill-prepared to negotiate potential conflict between their beliefs and reality of teaching, leading to dissonance and resistance to adaptation".

The results also reveal that STs receive feedback from the supervisors. Item no.14, The supervisor provides sufficient feedback (written and/or spoken) on student teachers' teaching style, ranks ninth and its PW is 81.3 and cannot be considered as a challenge. Item no.16 is about the period of time supervisors spend observing STs. The result shows that the CM and PW of this item is 2.12 and 70.6 successively. Moreover, Freiburg and Waxman (1990 cited in Bailey, 2006, p. 241) state that "much of the supervisor's time is consumed in travelling to and from various sites, with little time remaining for quality feedback". This may lead one to claim that the supervisors and their visits could create challenges. The fifteenth item of the STs' questionnaire ranks 18 and it is one of the challenges that STs face during their practicum. The item whether The supervisor visits the student teacher regularly or not has got 1.7 $\mathrm{CM}$ and 56.6 PW and this is a challenge for STs since this affects the supervisors' feedback negatively. So, it is recommended that supervisors should visit the STs more than once in order to have an adequate feedback on the STs' teaching performance. Moreover, the supervisors should be very cooperative with the STs and visit them regularly in order to reduce their anxiety. Finally, as the item I am aware of the evaluation criteria shows, the majority of STs are not aware of the evaluation criteria; according to item no.13, STs have no idea about the rubrics used to evaluate them and this may create a challenge. In order to solve this problem, English Department should inform EFL STs about the main points that evaluation is based on.

TABLE 3

CoEfFicient Midst (CM) AND Percentage Weight (PW) of Items of SUPERVISORS' EVALUATION CHALLENGES

\begin{tabular}{llllc}
\hline \hline No & \multicolumn{1}{c}{ Item } & CM & PW & Challenge? \\
\hline 14 & $\begin{array}{l}\text { The supervisor provides sufficient } \\
\text { feedback (written and/or spoken) } \\
\text { on student teachers' teaching } \\
\text { style. }\end{array}$ & 2.44 & 81.3 & No \\
16 & $\begin{array}{l}\text { The supervisor stays for an entire } \\
\text { lesson period during the } \\
\text { evaluation process. }\end{array}$ & 2.12 & 70.6 & No \\
15 & $\begin{array}{l}\text { The supervisor visits the student } \\
\text { teacher regularly. }\end{array}$ & 1.7 & 56.6 & Yes \\
13 & $\begin{array}{l}\text { I am aware of the evaluation } \\
\text { criteria. }\end{array}$ & 1.84 & 61.3 & Yes \\
\hline \hline
\end{tabular}




\section{Challenges of Lack of Materials}

Three items of the questionnaire are designed to check the challenges STs face because of lack of materials. Item no.19, All basic school students have the student book, activity book, and teacher book, cannot be regarded as a challenge since the schools provide all STs with the necessary books (teacher, student, activity). When STs visit basic schools to have their practicum, it is expected that the schools will provide them with necessary teaching aids. Item no.17 reveals something totally different from this. According to the result, this item has the value of 1.72 and percentage weight 57.3 and it is a challenge. So, the majority of STs are not provided with aids such as CD player, projectors, speakers, etc. Some of STs make these aids available while teaching. Another real challenges facing STs is lack of special room for teaching English; this room may help STs to have a better performance and make basic school students English more developed. The value item no.18, There is a special room for English (e.g., English zone), is 1.6 and its $\mathrm{PW}$ is 53.3. Building on this, one may state that the majority of basic schools in Sulaimani city do not have any special place for English (i.e., some certain zones for a language like English). In fact, this does not help STs to have a great opportunity to practice the knowledge they have acquired. To overcome some challenges, Peters $(2012$, p. 35) believes that STs "need to develop the skills and attitudes that enable them to critically reflect on others' and their own practice".

TABLE 4

CoEfFicient Midst (CM) AND Percentage Weight (PW) OF ITEMS OF LACK OF MATERIALS CHALLENGES

\begin{tabular}{clccc}
\hline \hline No & \multicolumn{1}{c}{ Item } & CM & PW & Challenge? \\
\hline 19 & $\begin{array}{l}\text { All basic school students have the } \\
\text { student book, activity book, and } \\
\text { teacher book. }\end{array}$ & 2.68 & 89.3 & No \\
& $\begin{array}{l}\text { The schools provide student } \\
\text { teachers with teaching aids (CD } \\
\text { player, projector, etc.) }\end{array}$ & & & \\
18 & $\begin{array}{l}\text { There is a special room for English } \\
\text { (e.g., English zone). }\end{array}$ & 1.6 & 53.3 & Yes \\
& & & Yes \\
\end{tabular}

\section{Challenges of Basic School Principal}

In general, practicum should offer STs an opportunity to have a feeling of being basic school teachers. Unfortunately, some basic school principals are not cooperative in this regard. Item no.11, I thought that student teachers are neglected by the school principal, with the CM of 1.7 and PW of 56.6 can be used as evidence that the majority of STs have a negative feeling towards basic school principals since they believe that they are ignored. Psychologically speaking, this negatively affects STs and their performance in teaching. Moreover, lack of principals' observation in order to evaluate STs' teaching methodology is one of the challenges. Item no.12, The principal observes student teachers' class to evaluate their teaching style, shows that its CM is 1.94 and its $\mathrm{PW}$ is 64.6. This can be considered as one of the problems since according to the practicum instructions the principal should evaluate STs out of 10 (see fig. 2). When school principals do not observe STs, how they evaluate STs' teaching ability, personality, behaviour inside the classroom and school. So, the result of their evaluation is not credible. On the other hand, item no.10 is about the possibility of treating STs as school teachers by the school principal; the item has got the value of 2.38 with the PW of 79.3 and it can be counted as a challenge.

TABLE 5

Coefficient Midst (CM) And Percentage Weight (PW) Challenges of BASIC SCHOOL PRINCIPAL ITEMS

\begin{tabular}{lllll}
\hline \hline No & \multicolumn{1}{c}{ Item } & CM & PW & Challenge? \\
\hline 10 & $\begin{array}{l}\text { The principal treats student teachers } \\
\text { as a school teacher. }\end{array}$ & 2.38 & 79.3 & No \\
& $\begin{array}{l}\text { The principal observes student } \\
\text { teachers' class to evaluate their } \\
\text { teaching style. }\end{array}$ & 1.94 & 64.6 & Yes \\
$11 \quad \begin{array}{l}\text { I thought that student teachers are } \\
\text { neglected by the school manager. }\end{array}$ & 1.7 & 56.6 & Yes \\
\hline \hline
\end{tabular}

\section{E. Some other Challenges}

According to the collected data, item no.9 of the questionnaire is achieved since its $\mathrm{CM}$ is above 2. This means that most of STs are informed by their university lecturers about practicum experience and this may positively affect the STs' teaching performance and reduce the challenges. Regarding the period of practicum, almost all STs believe that having only 45 days for practicing teaching English is not enough to apply the knowledge they have about teaching and acquire new ideas, techniques, etc. related to teaching. In item no.3, the present study focuses on the duration that STs spend at basic schools. This item with its $2.74 \mathrm{CM}$ and $91.3 \mathrm{PW}$ can be regarded as a challenge. Moreover, large classes can be considered a great challenge that faces STs since the majority of Sulaimani basic schools have this problem. The STs' response to The classes are large; 40 (and above) students are in each class reveals that STs may have problems in organizing and presenting their lessons since these require more effort and the basic school students may not cooperate.

TABLE 6

Coefficient Midst (CM) And Percentage Weight (PW) of Items of SOME OTHER CHALLENGES

\begin{tabular}{clccc}
\hline \hline No & \multicolumn{1}{c}{ Item } & CM & PW & Challenge? \\
\hline 3 & $\begin{array}{l}\text { The practicum period is short (i.e., } \\
\text { 45 days are not enough). }\end{array}$ & 2.74 & 91.3 & Yes \\
4 & $\begin{array}{l}\text { The classes are large; 40 (and } \\
\text { above) students are in each class. }\end{array}$ & 2.3 & 76.6 & Yes \\
9 & $\begin{array}{l}\text { I have enough information about } \\
\text { practicum experience. }\end{array}$ & 2.24 & 74.6 & No \\
\hline \hline
\end{tabular}




\section{CONCLUSIONS}

Practicum is one of the most important subjects in teacher education programs. Since Department of English, College of Basic Education, University of Sulaimani intends to prepare basic school English language teachers, the Department should work on factors which reduce the rate of challenges facing STs. Through experiencing practicum, STs gain more knowledge and practical experience in order to be successful basic school language teachers.

According to the analyzed data, the time allocated for Kurdish EFL practicum at College of Basic Education, University of Sulaimani is short; hence, it requires extension. The extension is invariable because this negatively affects the student teachers' performance. Moreover, basic school students prefer methods and techniques applied by basic school teachers (i.e., old-fashioned techniques). When STs attempt to apply modern methods of teaching, they face challenges and this may make basic school students unmotivated.

The main challenges Kurdish EFL student teachers encounter could be related to lack of learning basic skills, methods, and strategies of teaching inside the classroom. Almost all STs have problems regarding providing certain materials and following certain methods for teaching English. Lack of English zone can be considered one of the main challenges that STs have during practicum. The presence/absence of English zone may positively/negatively affect the practicum process. Generally speaking, STs are not fully aware of the items of the rubric used to evaluate their teaching performance. Consequently, this makes the practicum more challenging and may reduce the self-confidence they have in the process of teaching. Finally, the use of English by STs creates challenges; basic school students may not prefer using target language since most of basic school teachers of English mostly use Kurdish to explain the topics.

\section{RECOMMENDATIONS}

Building on the current study conclusions, it is recommended that preparing/writing a special guidance for Kurdish EFL STs by university specialists and experts could help STs to overcome the majority of challenges they face. The textbook may include the practicum main guidelines focusing on requirements, plans, supervision, evaluation, teaching, etc. Since the STs have taken courses such as "Methods of Teaching", "Language Testing", and "Pedagogical Technology" in the third year of their academic study, it is recommended to put "Teaching Practice" in the first semester of their fourth year; this gives them an opportunity to have more teaching practice. Moreover, "Observation" as a subject might be studied within the third year subjects. Thus, STs will have enough time to prepare themselves for their "Teaching Practice". In addition, Department of English, College of Basic Education may give an opportunity to practice the theoretical knowledge by STs at the Department before visiting basic schools so as to make them much more ready to face all expected challenges. This could be done through micro- teaching, especially when the STs were third year students. Lecturers who teach "Methods of Teaching" and "Pedagogical Technology" might be cooperative in this regard, and it will be better when STs are provided with teaching technological devices. Moreover, STs need to be familiar with professional culture. This could be achieved through introducing them to learning/teaching objectives, values, and challenges. Universities and basic schools should pay more attention to the practicum period of STs. They should design a systematic program and cooperate in order to reduce the challenges face EFL STs, since this may positively/negatively affect the STs' future career.

The present study recommends establishing an English zone at basic schools so that the basic school students can learn English more effectively and have daily activities and practice. Moreover, basic school teachers and STs will be able to have a better teaching performance. The study also recommends creating a teaching practice community at the university level, in order to help STs through sharing experiences, challenges, attitudes, etc. This would be very helpful in STs' preparation for the processes of learning and teaching. Furthermore, English Department should take into consideration notes by STs when they rejoin university to take all their notes, recommendations, and suggestions into consideration in order to make use of them in developing the practicum process for the next academic year and reduce the rate of challenges.

Finally, to have a better teaching practicum and overcome the challenges, College of Basic Education at the University of Sulaimani should design an adequate program in accordance with basic schools recommendations, which overall makes the STs well-prepared teachers in the future.

\section{REFERENCES}

Abu Omar, R., Aljazi, S., \& Al-Hasanat, H. (2018). Evaluation of teaching practicum at the college of educational sciences from the viewpoints of student teachers at Al-Hussein Bin Talal University (AHU). Journal of Studies in Education, 8(2), 45-70.

Bailey, K. (2006). Language teacher supervision: A case-based approach. Cambridge: Cambridge University Press.

Bailey, K. (2009). Issues in language teacher evaluation. In M. H. Long \& C. J. Doughty (Eds), The Handbook of language teaching (pp.706-725). United Kingdom: Blackwell Publishing Ltd.

Beck, C. \& Kosnik, C. (2002). Components of a good practicum placement: Student teacher perceptions. Teacher Education Quarterly, 29(2), 81-98.

Britzman, D. (1991). Practice makes practice. New York: State University of New York Press.

Collinson, V., Kozina, E., Lin, Y., Ling, L., Matheson, I., Newcornbe, L. \& Zogla, I. (2009). Professional development to teachers: A world of change. European Journal of Teacher Education, 32(1), 3-19.

Farrell, Th. (2007). Failing the practicum: Narrowing the gap between expectations and reality with reflective practice. TESOL Quarterly, 41(1), 193-201.

Gebhard, J. (2006). Teaching English as a foreign or a second language: A teacher self-development and methodology guide. ( $2^{\text {nd }}$ Edition). USA: The University of Michigan Press.

Handal, G., \& Lauvas, P. (1987). Promoting reflective teaching. Milton Keynes: Open University Press. 
He, Y. (2009). Strength-based mentoring in pre-service teacher education: A literature review. Mentoring \& Tutoring: Partnership in Learning, 17(3), 263-275.

Hoben, G. \& Brickell, G. (2006). Using diagrams as reflective tools to represent the dynamics of classroom interaction. In P. Aubusson \& S. Schuck (Eds), Teacher learning and development: The minor maze (pp. 237-250). The Netherlands: Springer.

Darling-Hammond, L. \& Bransford, J. (2005). Preparing teachers for a changing world: What teachers should learn and be able to do. San Francisco: Jossey-Bass.

Johnson, K. (2009). Second language teacher education: A sociocultural perspective. UK: Taylor \& Francis.

Kumaravadivelu, B. (2006). Understanding language teaching: From method to postmethod. New Jersey: Lawrence Erlbaum Associates, Inc.

Loucks-Horsley, S., Stiles, K., Mundry, S., Love, N. \& Hewson, P. (2010). Designing professional development for teachers of science and mathematics. ( ${ }^{\text {rd }}$ Edition). California: Corwin.

Marais, P. \& Meier, C. (2004). Hear our voices: Student teacher's experience during practical teaching. Africa Education Review, 1(2), 220-233.

Mills, J. R. (1980). A guide to teaching systematic observation to student teachers. Journal of Teacher Education, 31(6), 5-9.

Ogonor, B. O. \& Badmus, M. M. (2006). Reflective teaching practice among student teachers: The case in tertiary institution in Nigeria. The Australian Journal of Teacher Education, 31(2), 1-11.

Peters, J. H. (2012). Are they ready? Final year pre-service teachers' learning about managing student behaviour. The Australian Journal of Teacher Education, 37(9), 18-42

Prebble, T., Hargraves, H., Leach, L., Naidoo, K., Suddaby, G. \& Zepke, N. (2004). Impact of student support services and academic development programmes on student outcomes in undergraduate tertiary study: A synthesis of the research (Report to the Ministry of Education). Retrieved from

https://www.educationcounts.govt.nz/_data/assets/pdf_file/0013/7321/u gradstudentoutcomes.pdf (29 September 2018)

Richards, J. (2012). Competence and performance in language teaching. In A. Burns \& J. C. Richards (Eds), The Cambridge guide to pedagogy and practice in second language teaching (pp. 46-59). Cambridge: Cambridge University Press.

Ryan, G., Toohey, S., \& Hughes, C. (1996). The purpose, value and structure of the practicum in higher education: A literature review. Higher Education, 31(3), 355-377.

Tarone, E. \& Allwright, D. (2005). Second language teacher learning and student second language learning: Shaping the knowledge base. In D. J. Tedick (Ed), Second language teacher education: International perspectives (pp. 5-23). New Jersey: Lawrence Erlbaum Associates, Inc.

Zeichner, K. (2006). Reflections of a university based teacher educator on the future of college and university-based teacher education. Journal of Teacher Education, 50(3), 326-340.b

\section{APPENDIX}

\section{Student Teachers' Questionnaire}

Dear student teachers,

This questionnaire is designed to investigate the challenges you face during your teaching practice period. Kindly read the items and tick only one option. Thanks for your corporation.

\begin{tabular}{|c|c|c|c|c|}
\hline No & Item & Agree & Neutral & Disagree \\
\hline 1 & $\begin{array}{l}\text { Basic school teachers have } \\
\text { used L1 and I cannot use L2 } \\
\text { most of the time }\end{array}$ & & & \\
\hline 2 & $\begin{array}{l}\text { Basic school students prefer } \\
\text { traditional methods of } \\
\text { learning/teaching }\end{array}$ & & & \\
\hline 3 & $\begin{array}{l}\text { The practicum period is short } \\
\text { (i.e., } 45 \text { days are not enough). }\end{array}$ & & & \\
\hline 4 & $\begin{array}{l}\text { The classes are large; } 40 \text { (and } \\
\text { above) students are in each } \\
\text { class. }\end{array}$ & & & \\
\hline 5 & $\begin{array}{l}\text { Basic school students are } \\
\text { motivated to learn English }\end{array}$ & & & \\
\hline 6 & $\begin{array}{l}\text { I am able to write a lesson } \\
\text { plan. }\end{array}$ & & & \\
\hline 7 & $\begin{array}{l}\text { I am able to explain all topics } \\
\text { since I have an idea about the } \\
\text { textbook. }\end{array}$ & & & \\
\hline 8 & $\begin{array}{l}\text { I am able to design questions } \\
\text { for course exam. }\end{array}$ & & & \\
\hline 9 & $\begin{array}{l}\text { I have enough information } \\
\text { about practicum experience. }\end{array}$ & & & \\
\hline 10 & $\begin{array}{l}\text { The principal treats student } \\
\text { teachers as a school teacher. }\end{array}$ & & & \\
\hline 11 & $\begin{array}{l}\text { I thought that student teachers } \\
\text { are neglected by the school } \\
\text { manager. }\end{array}$ & & & \\
\hline 12 & $\begin{array}{l}\text { The principal observes student } \\
\text { teachers' class to evaluate their } \\
\text { teaching style. }\end{array}$ & & & \\
\hline 13 & $\begin{array}{l}\text { I am aware of the evaluation } \\
\text { criteria. }\end{array}$ & & & \\
\hline 14 & $\begin{array}{l}\text { The supervisor provides } \\
\text { sufficient feedback (written } \\
\text { and/or spoken) on student } \\
\text { teachers' teaching style. }\end{array}$ & & & \\
\hline 15 & $\begin{array}{l}\text { The supervisor visits the } \\
\text { student teacher regularly. }\end{array}$ & & & \\
\hline 16 & $\begin{array}{l}\text { The supervisor stays for an } \\
\text { entire lesson period during the } \\
\text { evaluation process. }\end{array}$ & & & \\
\hline 17 & $\begin{array}{l}\text { The schools provide student } \\
\text { teachers with teaching aids } \\
\text { (CD player, projector, etc.) }\end{array}$ & & & \\
\hline 18 & $\begin{array}{l}\text { There is a special room for } \\
\text { English (e.g., English zone). }\end{array}$ & & & \\
\hline 19 & $\begin{array}{l}\text { All basic school students have } \\
\text { the student book, activity } \\
\text { book, and teacher book. }\end{array}$ & & & \\
\hline 20 & $\begin{array}{l}\text { I am able to use English while } \\
\text { teaching. }\end{array}$ & & & \\
\hline
\end{tabular}

